\title{
Photoperiod Affects Gene Expression of Leptin and Leptin Receptors in Adipose Tissue from Lactating Dairy Cows ${ }^{1}$
}

\author{
U. Bernabucci, ${ }^{\star 2}$ L. Basiricò, ${ }^{\star}$ N. Lacetera, ${ }^{*}$ P. Morera, ${ }^{*}$ B. Ronchi, ${ }^{\star}$ P. A. Accorsi, $\dagger$ \\ E. Seren, $\dagger$ and A. Nardone* \\ *Dipartimento di Produzioni Animali, Università degli Studi della Tuscia, Viterbo, Italia \\ †Dipartimento di Morfofisiologia Veterinaria e Produzioni Animali, Università di Bologna, Italia
}

\begin{abstract}
Leptin is mainly secreted by adipocytes and is implicated in the regulation of metabolic status, feed intake, and body condition. Day length (DL) can affect leptin gene expression and secretion. The aim of the study was to evaluate the effect of DL on gene expression of leptin and leptin receptors in adipose tissue (AT). Four lactating and pregnant Holstein cows were housed in a climate-controlled chamber for $51 \mathrm{~d}$. The first $30 \mathrm{~d}$ were used to adapt animals to the new housing conditions. During that period the DL adopted was $12 \mathrm{~h}$ light:12 $\mathrm{h}$ dark (12:12). The experimental period included 3 different and consecutive phases: $7 \mathrm{~d}$ of neutral DL (12:12); $7 \mathrm{~d}$ of long DL (18 h light:6 h dark); and 7 d of short DL (6 h light:18 h dark). Subcutaneous AT biopsies were performed at the end of each phase. Prolactin, growth hormone, cortisol, leptin, glucose, nonesterified fatty acids, $\beta$-OH-butyrate, and cholesterol were determined in plasma samples. Abundance of leptin mRNA, and Ob-Ra and Ob-Rb leptin receptor mRNA were determined in AT samples by ribonuclease protection assay. Day length did not affect feed intake or body condition score. Exposure to short DL significantly reduced milk yield ( $13.1 \pm 2.2$ vs. $15.8 \pm 1.7$ and $16.0 \pm$ $2.0 \mathrm{~kg} / \mathrm{d}$ for short vs. neutral and long DL, respectively). Plasma leptin, growth hormone, cortisol, nonesterified fatty acids, $\beta$-OH-butyrate, and glucose were not affected by DL; cholesterol was lowest under short DL $(3.93 \pm 0.38$ vs. $4.36 \pm 0.39$ and $4.07 \pm 0.38 \mathrm{mmol} / \mathrm{L}$ for short vs. neutral and long DL, respectively). Prolactin increased under long DL $(134.82 \pm 16.94$ vs. $81.98 \pm$ 20.25 and $96.16 \pm 0.38 \mathrm{ng} / \mathrm{mL}$ for long vs. neutral and short DL, respectively). Gene expression of leptin and its receptors was affected by DL. Leptin mRNA increased under long DL ( $11.91 \pm 0.84$ vs. $7.82 \pm 0.84$ and $7.56 \pm 0.84 \mathrm{pg}$ of $\mathrm{mRNA} / \mu \mathrm{g}$ of total RNA for long vs.
\end{abstract}

\footnotetext{
Received April 13, 2006.

Accepted July 14, 2006.

${ }^{1}$ The research was financially supported by MURST - FIRB

${ }^{2}$ Corresponding author: bernab@unitus.it
} Project. neutral and short DL, respectively). Leptin receptors $\mathrm{Ob}-\mathrm{Ra}$ and $\mathrm{Ob}-\mathrm{Rb}$ mRNA were higher under long DL, whereas $\mathrm{Ob}-\mathrm{Ra}$ and $\mathrm{Ob}-\mathrm{Rb} \mathrm{mRNA}$ were lower under short DL (Ob-Ra: $1.91 \pm 0.41,2.49 \pm 0.41$, and $0.65 \pm$ $0.41 \mathrm{pg}$ of $\mathrm{mRNA} / \mu \mathrm{g}$ of total RNA for neutral, long, and short DL, respectively; Ob-Rb: $5.29 \pm 0.79,5.98 \pm 0.68$, and $2.02 \pm 0.70 \mathrm{pg}$ of $\mathrm{mRNA} / \mu \mathrm{g}$ of total RNA for neutral, long, and short DL, respectively). Results of the present study appear to exclude an effect of feed intake and metabolic status on leptin gene expression. A prolactinmediated effect of photoperiod on AT leptin modulation may be proposed in lactating dairy cows.

Key words: leptin, leptin receptor, dairy cow adipose tissue, photoperiod

\section{INTRODUCTION}

Leptin is a protein hormone secreted predominantly by adipocytes. However, the leptin gene is also expressed in placenta and fetal tissues, in mammary gland, the stomach, and skeletal muscle in ruminants (Chilliard et al., 2005) and in other species (Ahima and Flier, 2000). Leptin plays a central role in the regulation of energy homeostasis and food intake, through an action on the hypothalamus and peripheral targets. Additionally, leptin is implicated in the regulation of reproduction, immune function, blood pressure, angiogenesis, renal function, and bone formation (Frühbeck, 2001).

Leptin acts via transmembrane receptors, which show structural similarity to those of the type I cytokine receptor family. Leptin receptors are present in 6 differently spliced isoforms named Ob-Ra to Ob-Rf. These isoforms have identical extracellular and transmembrane domains, but differ in their intracellular domains. Among these isoforms, only the long isoform (Ob-Rb), with the complete intracellular domain, is fully functional and is responsible for most of the physiological effects of leptin (Sweeney, 2002). The short form (Ob-Ra), with a truncated intracellular domain, is the smallest receptor with biological activity, whereas the other variants (Ob-Rc, d, e, and f) are important in hormone binding and transport. The expression of func- 
tional leptin receptors is highest in the central nervous system, but they are also distributed in various peripheral tissues, explaining the pleiotropic effect of leptin. Gene expression or secretion of leptin undergoes significant seasonal fluctuations associated with changes of food availability, levels of body reserves, and day length (DL; Frühbeck, 2001).

Investigations on the photoperiodic regulation of leptin levels in ruminants have yielded contradictory results and led to different interpretations. Plasma leptin levels and perirenal adipose tissue (AT) leptin gene expression were decreased in ovariectomized ewes exposed to short days under different feeding regimens (Bocquier et al., 1998). Those authors concluded that leptin is modulated by DL independently of food intake, fatness, and gonadal activity. Similarly, in ovariectomized cows the serum leptin levels were lower in winter than in summer without a change in BW (Garcia et al., 2002). To our knowledge, few and inconclusive data are available in the literature on the effect of DL on leptin in lactating dairy cows. Therefore, our aim was to evaluate changes of AT gene expression of leptin and its receptors in lactating dairy cows exposed to different DL.

\section{MATERIALS AND METHODS}

\section{Animals, Housing, and Feeding}

Four pregnant $(95 \pm 4 \mathrm{~d})$, late-lactating (223 \pm 60 DIM), and multiparous ( $3 \pm 1$ ) Holstein cows were used. The animals were housed in a climate-controlled chamber with individual tie stalls equipped with individual feeders and water bowls at an ambient temperature of $18^{\circ} \mathrm{C}, 65 \%$ relative humidity, and $1.4 \mathrm{~m}^{3} / \mathrm{min}$ of air circulation by way of a forced-air circulation system. The chamber was $5.6 \mathrm{~m}$ wide, $10.0 \mathrm{~m}$ long, and had a capacity of $162.4 \mathrm{~m}^{3}$. Ambient temperature and relative humidity were computer-controlled using heater and refrigerator units that were monitored continuously. The chamber was equipped with fluorescent lighting. Cows were milked twice a day at 0730 and at $1730 \mathrm{~h}$.

The animals were fed individually a diet consisted of hay (alfalfa and rye-grass; Table 1) and commercial mixed feed (CMF). The diet was given as follows (percentage of the total amount fed per day): $50 \%$ hay + $33.3 \% \mathrm{CMF}$ at $0800 \mathrm{~h}, 33.3 \% \mathrm{CMF}$ at $1200 \mathrm{~h}$, and $50 \%$ hay $+33.3 \% \mathrm{CMF}$ at $1600 \mathrm{~h}$.

\section{Experimental Design}

The trial was $51 \mathrm{~d}$, with the first $30 \mathrm{~d}$ used to adapt animals to the new housing conditions. During that period the DL was $12 \mathrm{~h}$ light (400 lx):12 h dark (12:12). The experimental period was $21 \mathrm{~d}$ and included 3 different and consecutive phases: $7 \mathrm{~d}$ of neutral DL (12:12);
Table 1. Characteristics of hays and commercial mixed feed (CMF) administered during the experimental period (on DM basis)

\begin{tabular}{lccc}
\hline & $\begin{array}{l}\text { Alfalfa } \\
\text { hay }\end{array}$ & $\begin{array}{l}\text { Ryegrass } \\
\text { hay }\end{array}$ & CMF $^{1}$ \\
\hline DM, \% & 88.3 & 88.0 & 87.0 \\
CP, \% & 16.4 & 11.2 & 20.4 \\
Crude fiber, \% & 36.0 & 30.2 & 10.8 \\
Ether extract, \% & 1.8 & 3.0 & 4.3 \\
Ash, \% & 8.0 & 10.5 & 10.0 \\
NDF, \% & 53.7 & 54.0 & 23.5 \\
ADF, \% & 39.8 & 36.2 & 12.7 \\
ADL, \% & 9.0 & 5.4 & 2.3 \\
$\mathrm{NE}_{\mathrm{L}}$, Mcal/kg & 1.19 & 1.28 & 2.25 \\
\hline
\end{tabular}

${ }^{1}$ Contained: $100,000 \mathrm{IU}$ vitamin A, 8,000 IU vitamin $\mathrm{D}, 100 \mathrm{mg}$ vitamin $\mathrm{E}, 500 \mathrm{mg}$ niacin, $10.4 \mathrm{mg}$ vitamin $\mathrm{B}_{1}, 14 \mathrm{mg}$ vitamin $\mathrm{B}_{2}, 4$ $\mathrm{mg}$ vitamin $\mathrm{B}_{6}, 0.1 \mathrm{mg}$ vitamin $\mathrm{B}_{12}, 200 \mathrm{mg} \mathrm{Fe}, 30 \mathrm{mg} \mathrm{Cu}, 160 \mathrm{mg}$ $\mathrm{Mg}, 4.4 \mathrm{mg} \mathrm{Co}, 10.8 \mathrm{mg}$ I, $360 \mathrm{mg} \mathrm{Zn}$, and $0.6 \mathrm{mg} \mathrm{Se} / \mathrm{kg}$.

${ }^{2} \mathrm{ADL}=$ Acid detergent lignin.

$7 \mathrm{~d}$ of long DL (18:6); and $7 \mathrm{~d}$ of short DL (6:18). The short DL treatment period $(7 \mathrm{~d})$ was chosen to avoid or reduce the effect of different DL on feed intake, adiposity, and metabolic parameters. During the short DL treatment, low-intensity red lights (approximately 7.5 W) were used to allow personnel to feed and milk animals. Timers to control the lights were used to avoid human error and maintain consistency of the lighting schedule.

\section{Measurements and Samplings}

Dry matter intake was measured once daily at 0800 h. The BCS was determined according to criteria described by the Agricultural Development and Advisory Service (1986) at the end of each experimental phase. Milk yield (MY) was measured at each milking using calibrated weigh jars.

Blood samples were collected 4 times a day (0600, 1200,1800 , and $2400 \mathrm{~h}$ ) from the jugular vein into heparinized Vacutainer tubes (Vacutainer System, Plymouth, UK) at the middle and at the end of each phase. Blood samples were centrifuged at $3,500 \times g$ for 15 min at $4^{\circ} \mathrm{C}$, and plasma was stored at $-20^{\circ} \mathrm{C}$ until the analysis. Blood samples were pooled to obtain a value representative of the $24-\mathrm{h}$ period, avoiding the possible interferences due to changes in the light:dark cycle.

Subcutaneous AT biopsies (three 5-g samples) were collected near the tail-head at the end of each phase from each cow. Immediately after collection, AT samples were rinsed in RNase-free water (diethyl pyrocarbonate-treated water), frozen in liquid nitrogen, and stored at $-80^{\circ} \mathrm{C}$ until the ribonuclease protection assay (RPA) of mRNA. 


\section{Laboratory Analyses}

Feedstuffs. Feeds were sampled and analyzed. Dry matter was determined by forced-air oven drying at $65^{\circ} \mathrm{C}$ to constant weight. Crude protein was determined by macro-Kjeldahl method (AOAC, 1984). Ether extract and ash were determined according to AOAC methods (AOAC, 1984). The NDF, ADF, and acid detergent lignin were analyzed according to the method described by Goering and Van Soest (1970).

Blood Metabolites and Hormones. Plasma glucose and cholesterol (kits from Instrumentation Laboratory, Lexington, MA), BHBA (Barnouin et al., 1986), and NEFA (NEFA-C kit; Wako Fine Chemical Industries USA, Inc., Dallas TX) were determined by an automatic analyzer (Monarch 1500-Plus, International Laboratory, Lexington, IL).

Plasma growth hormone (GH) and prolactin (PRL) were assayed by validated double-antibody RIA (Accorsi et al., 2005). Assay sensitivity was $0.5 \pm 0.12 \mathrm{ng} /$ $\mathrm{mL}$ for $\mathrm{GH}$ and $1.3 \pm 0.25 \mathrm{ng} / \mathrm{mL}$ for PRL. The intraand interassay coefficients of variation were $<9$ and $15 \%$ for both assays, respectively.

A commercially available kit was used to determine leptin (Multispecies Leptin RIA kit; Linco Research, St. Louis, MO). Recombinant bovine leptin (rbLeptin, DSL, Webster, TX) was used to construct a standard curve. As reported by Delavaud et al. (2000), the "multispecies" commercial RIA kit, despite some limitations (mainly because of a low sensitivity of the antibody in the low range of leptin values), is as effective and reliable as an ovine-specific RIA in determining leptin plasma profiles in the bovine species. The sensitivity of leptin assay, defined as $90 \%$ of total binding, was $0.37 \pm 0.01 \mathrm{ng} / \mathrm{mL}$; the intra- and interassay coefficients of variation were 4.2 and $8 \%$, respectively. Parallelism with standard curves and scalar dilution of bovine plasma performed for all assays did not show any significant differences. Recovery was $94.8 \pm 3 \%$.

Plasma cortisol concentrations were evaluated using an RIA. The sensitivity (90\% bound/unbound) of the cortisol antibody was $4.93 \mathrm{ng} / \mathrm{mL}$, and the cross-reactivities were: $20.4 \%$ with cortisone, $4.6 \%$ with deoxycortisol-11a, $1.13 \%$ with corticosterone, and $0 \%$ with progesterone and estrogens (Ronchi et al., 2001).

AT Leptin and Leptin Receptor mRNA Abundance. Total RNA was isolated by homogenizing AT in TRI Reagent solution containing phenol and guanidine thiocyanate (Sigma-Aldrich, Milan, Italy) following the procedure described by Bernabucci et al. (2004). Total RNA was quantified by measuring absorbance at 260 $\mathrm{nm}$. To verify integrity, cellular RNA was electrophoresed on $1.2 \%$ agarose and stained with ethidium bromide. Cellular RNA that had intact $28 \mathrm{~S}$ and $18 \mathrm{~S}$ ribo- somal bands was used in subsequent analyses. Isolated RNA was stored at $-80^{\circ} \mathrm{C}$ until the RPA.

Specific antisense ribonucleotide probes were generated using cDNA of leptin, Ob-Ra, Ob-Rb, and GAPDH, which was used as internal control, and were produced from bovine AT RNA by reverse transcription-PCR (RTPCR). The primers were designed using published leptin and GAPDH bovine nucleic acid sequences, whereas oligonucleotide primer pairs specific for $\mathrm{Ob}-\mathrm{Rb}$ and $\mathrm{Ob}-$ $\mathrm{Ra}$ were designed based on the known human Ob-Rb and Ob-Ra sequence. Primer information is listed in Table 2.

The reverse transcription reaction was carried out using the Superscript II kit (Gibco-BRL, Life Technologies, Gaithersburg, MD) according to the manufacturer's instructions. The total PCR reaction mixture of 100 $\mu \mathrm{L}$ contained $5 \mathrm{U}$ of Taq DNA polymerase (Gibco-BRL). To confirm leptin, its receptors, and GAPDH RT-PCR products, all products were run on agarose gel to verify the expected length of the products and the presence of a single band. Finally, the RT-PCR products were sequenced directly after purification with primers used in the original amplification reaction by an automated DNA sequencer (CEQ8800 sequencer using DTCS QuickStart Kit; Beckman Coulter, Fullerton, CA) according to the manufacturer's instructions. The sequence data were analyzed and aligned with Bioedit software (Tom Hall, Ibis Therapeutics, Carlsbad, CA).

The PCR products, containing sequence of the T7 promoter at the $5^{\prime}$ end, were transcribed in vitro directly using a Maxiscript transcription Kit (Ambion, Inc., Austin, TX) according to the manufacturer's instructions. After transcription, all riboprobes were purified and labeled with biotin using Brighstar Psoralen-Biotin Kit (Ambion, Inc.) according to the manufacturer's instructions.

Multiple-probe RPA was performed as described by Bernabucci et al. (2004). Briefly, hybridization of total RNA with riboprobes was carried out using the RPA III kit (Ambion, Inc.) as described for the standard procedure. Target RNA samples and riboprobes were coprecipitated with ammonium acetate and ethanol. Yeast RNA from the RPA III kit was used as negative control. The RNA samples and riboprobes were subsequently processed following the procedure described by the manufacturer (Ambion, Inc.). The samples were loaded on acrylamide gel and then electrophoretically transferred to a positively charged nylon membrane (BrightStar-Plus, Ambion, Inc.).

For the quantitative analysis of leptin, Ob-Ra, and Ob-Rb mRNA, known amounts of in vitro synthesized leptin, Ob-Ra, and Ob-Rb sense RNA were hybridized with an excess of labeled antisense probes to construct the standard curves. Figure 1 shows an example of a 
Table 2. Sequences of primers, position in coding sequence, PCR product length, and European Molecular Biology Laboratory (EMBL) accession number of the used published bovine and human nucleic acid sequences $^{1}$

\begin{tabular}{|c|c|c|c|c|c|}
\hline Gene $^{2}$ & & Primer sequence $\left(5^{\prime} \rightarrow 3^{\prime}\right)$ & Position & $\begin{array}{l}\text { Length, } \\
\text { bp }\end{array}$ & $\begin{array}{l}\text { EMBL } \\
\text { no. }\end{array}$ \\
\hline \multirow[t]{2}{*}{ Leptin } & Forward & ACATCTCACACACGCAGTCC & 131 & \multirow[t]{2}{*}{182} & \multirow[t]{2}{*}{ U43943 } \\
\hline & Reverse & GAGGTTCTCCAGGTCATTGG & 312 & & \\
\hline \multirow[t]{2}{*}{ Ob-Ra } & Forward & GAGAAGTACCAGTTCAGTC & 2,413 & \multirow[t]{2}{*}{275} & \multirow{2}{*}{ U50748 } \\
\hline & Reverse & CAAAGAATGTCCGTTCTCTTC & 2,690 & & \\
\hline \multirow[t]{2}{*}{ Ob-Rb } & Forward & ATCAGTGTTGATACATCATGGAAA & 2,957 & \multirow[t]{2}{*}{402} & \multirow[t]{2}{*}{ U43168 } \\
\hline & Reverse & TGAGAATGTGAGGTGTGGTGAAAT & 3,355 & & \\
\hline \multirow[t]{2}{*}{ GAPDH } & Forward & TCATCCCTGCTTCTACTGGC & 581 & \multirow[t]{2}{*}{177} & \multirow[t]{2}{*}{ U85042 } \\
\hline & Reverse & CCTGCTTCACCACCTTCTTG & 757 & & \\
\hline
\end{tabular}

\footnotetext{
${ }^{1}$ The sequence of T7 promoter for reverse primers only was: TAATACGACTCACTATAGGGAG.

${ }^{2} \mathrm{Ob}-\mathrm{Ra}=$ Short-form leptin receptor; Ob-Rb = long-form leptin receptor; GAPDH = glyceraldehyde-3phosphate dehydrogenase
}

standard curve for leptin. The mRNA was cross-linked to the wet membrane after the transfer. The nonisotopic detection of the probe fragments protected was performed using BrightStar and BioDetect kits (Ambion, Inc.) following the procedure described by the manufacturer.

Chemiluminescent films were analyzed with the Kodak EDAS-290 densitometer and ID Image Analysis software (Eastman Kodak Company, Rochester, NY). Figure 2 shows representative RPA images for leptin receptors, leptin, and GAPDH mRNA. Samples were analyzed in conjunction with the standard curve and the intensity of the probe fragments protected by un-

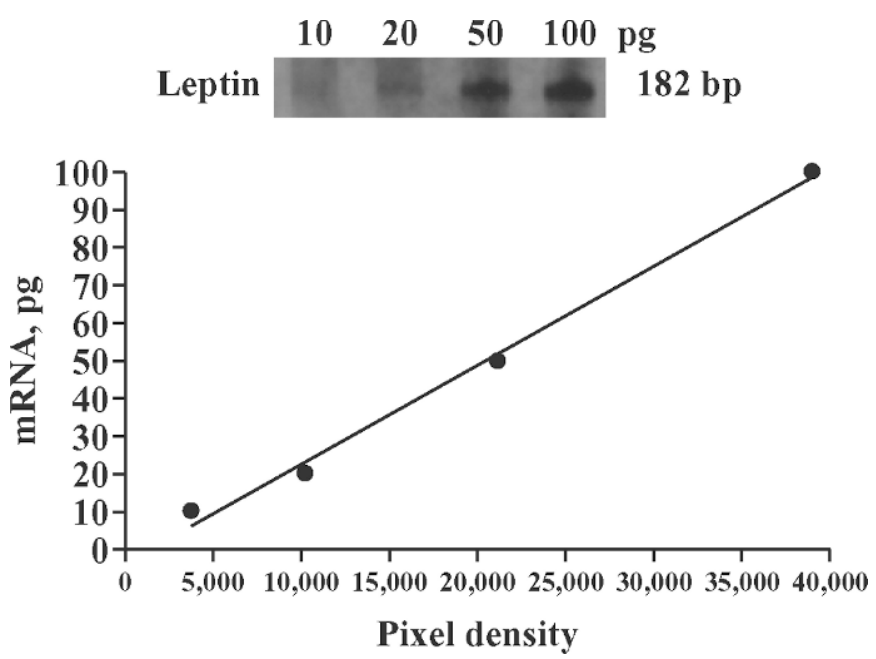

Figure 1. Example of a standard concentration curve constructed using known amounts of in vitro synthesized sense-strand RNA hybridized with an excess of labeled antisense probe. Ribonuclease protection assays were performed on 10-, 20-, 50-, and 100-pg samples of leptin sense RNA $\left(y=0.0026 x-3.4609 ; R^{2}=0.994\right)$. The reaction products were resolved on a denaturing $5 \%$ polyacrylamide gel and then quantified with the Kodak EDAS-290 densitometer and ID Image Analysis software (Eastman Kodak Company, Rochester, NY). known samples was compared with the standard curve to determine the absolute amounts of leptin, Ob-Ra, and $\mathrm{Ob}-\mathrm{Rb}$ mRNA.

\section{Statistical Analysis}

Data for all variables measured were analyzed as repeated measures using the MIXED procedure of SAS (SAS Institute, 1999). The model included fixed effects (photoperiod treatment: 1, 2, 3), sampling day $(1,2)$, time of sampling $(1, . ., 4)$, random effects (cow), and the error term. Feed intake and MY variables were

\section{Photoperiod}

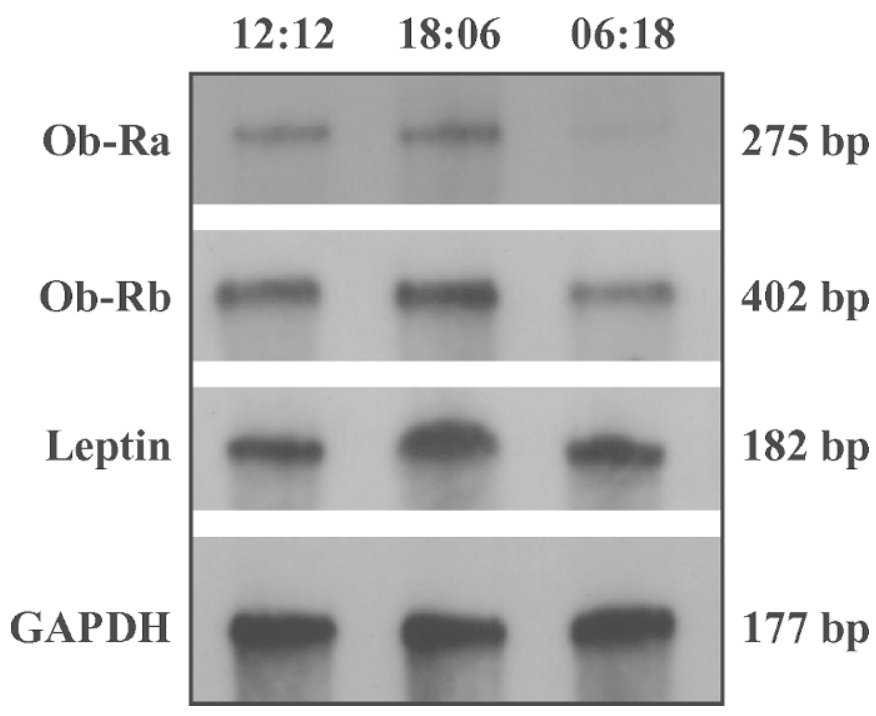

Figure 2. Representative ribonuclease protection assay images of short form (Ob-Ra) and long form (Ob-Rb) leptin receptors, leptin, and glyceraldehyde-3-phosphate dehydrogenase (GAPDH) mRNA. Photoperiods are 12:12, 18:6, and 6:18 h of light:dark. 


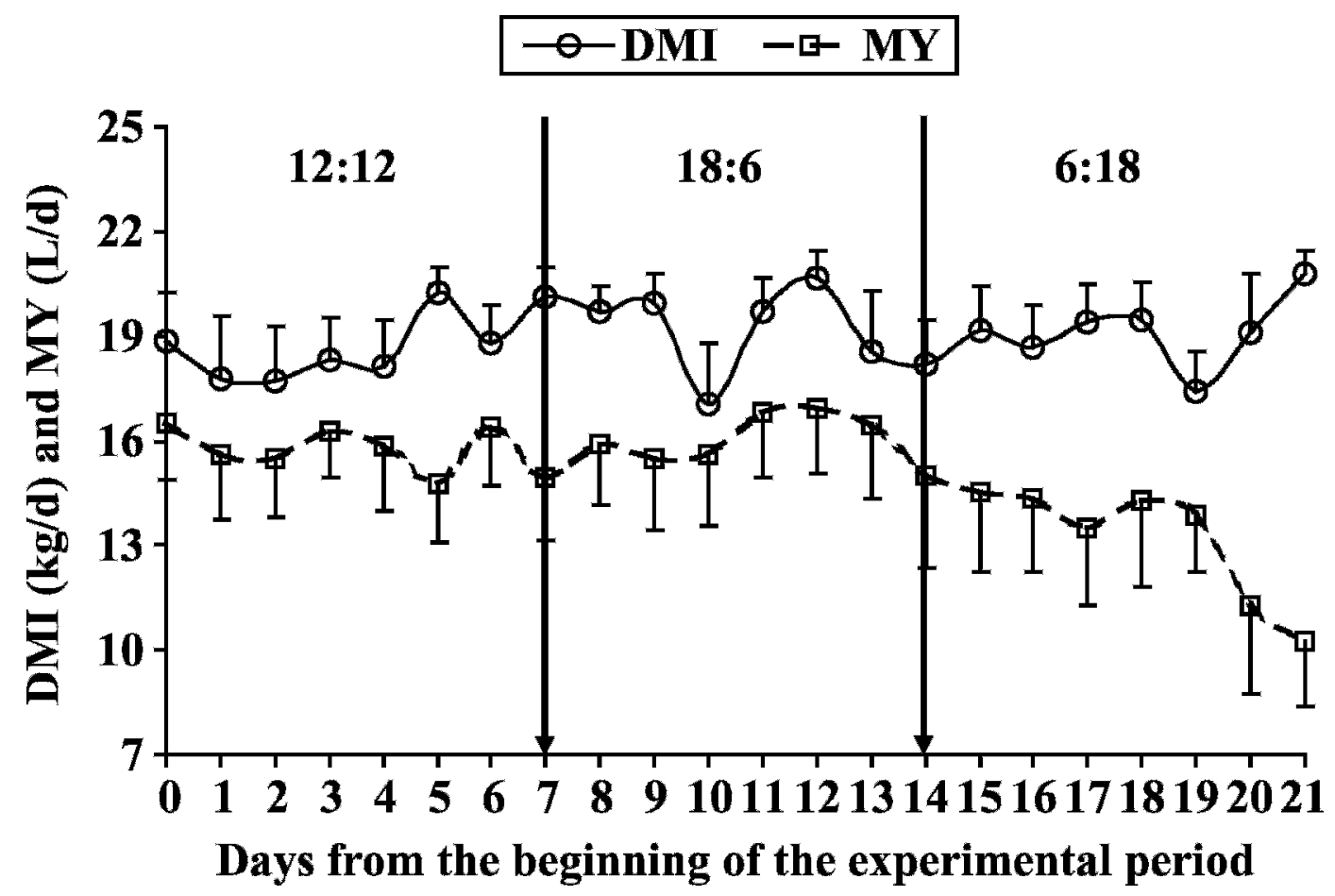

Figure 3. Changes of DMI and milk yield (MY) in lactating dairy cows exposed to different photoperiods: neutral (12:12), long (18:6), and short (6:18) day lengths (in hours of light:dark). Only MY had significant contrasts: short vs. neutral and long day length $(P<0.05)$; no difference between neutral and long day lengths was observed. Data represent least squares means \pm SEM.

analyzed using a model that included fixed effects (photoperiod treatment: $1,2,3$ ) and day of measurement $(1, . ., 21)$, random effects (cow), and the error term.

For each analyzed variable, cow was subjected to 3 covariance structures: compound symmetric, autoregressive order one, and unstructured covariance. The covariance structure that had the largest Akaike's information criterion and Schwarz's Bayesian criterion was considered the most desirable analysis. Least squares means were separated with the PDIFF procedure of SAS (SAS Institute, 1999). Data are reported as least squares means with standard errors. Correlation coefficients among different variables were determined by the CORR procedure of SAS (SAS Institute, 1999). Significance was declared at $P<0.05$.

\section{RESULTS}

\section{$D M I, M Y$, and BCS}

Dry matter intake and MY of cows exposed to different photoperiods are shown in Figure 3. Feed intake did not differ between all experimental phases (18.7 \pm $1.2,19.3 \pm 1.1$, and $19.0 \pm 1.2 \mathrm{~kg} / \mathrm{d}$ for neutral, long, and short DL, respectively). On the contrary, MY was lower in cows exposed to short DL (6:18), compared with that of neutral (12:12) and long DL (18:6) cows
$(13.1 \pm 2.2$ vs. $15.8 \pm 1.7$ and $16.0 \pm 2.0 \mathrm{~kg} / \mathrm{d}$, respectively; $P<0.05)$. No changes of BCS were observed during the experimental period for all cows (Table 3 ).

\section{Metabolic and Hormonal Parameters}

Plasma glucose, NEFA, and BHBA were not affected by DL (Table 3$)$. Plasma cholesterol was lower $(P<0.05)$ during the short DL compared with the neutral and long DL. No differences were observed between the neutral and long DL phases.

Plasma concentration of PRL increased (Table 3; $P$ $<0.01$ ) under long DL compared with neutral and short DL. No changes were observed in GH, cortisol, and leptin between treatments. The higher concentration of PRL observed under long DL was due to the values recorded on d 7 (Figure 4).

Daytime shifts in PRL concentration on $\mathrm{d} 7$ of the long DL treatment were: $178.4 \pm 13.6,206.8 \pm 28.6$, $198.3 \pm 16.3$, and $81.8 \pm 12.7 \mathrm{ng} / \mathrm{mL}$ at $0600,1200,1800$, and $2400 \mathrm{~h}$, respectively. Prolactin concentration was lowest $(P<0.05)$ at $2400 \mathrm{~h}$ and highest $(P<0.05)$ at $1200 \mathrm{~h}$. Daytime shifts in PRL concentration on $\mathrm{d} 7$ of the short DL treatment were: $100.6 \pm 21.5,89.1 \pm 15.8$, $85.1 \pm 13.2$, and $92.9 \pm 17.7 \mathrm{ng} / \mathrm{mL}$ at $0600,1200,1800$ and $2400 \mathrm{~h}$, respectively. Prolactin was higher $(P<0.05)$ at $0600 \mathrm{~h}$ when compared with $1800 \mathrm{~h}$. 
Table 3. Least squares means $( \pm \mathrm{SE})$ for BCS and plasma metabolic and hormonal parameters for neutral, long, and short day lengths

\begin{tabular}{lrrr}
\hline & \multicolumn{3}{c}{ Photoperiod (hours of light:dark) } \\
\cline { 2 - 4 } & Neutral $(12: 12)$ & Long $(18: 6)$ & Short (6:18) \\
\hline BCS & $3.0 \pm 0.3$ & $2.9 \pm 0.4$ & $3.1 \pm 0.3$ \\
Glucose, mmol/L & $3.43 \pm 0.09$ & $3.41 \pm 0.08$ & $3.55 \pm 0.08$ \\
NEFA, mmol/L & $0.196 \pm 0.052$ & $0.210 \pm 0.050$ & $0.233 \pm 0.050$ \\
BHBA, mmol/L & $0.400 \pm 0.037$ & $0.400 \pm 0.035$ & $0.412 \pm 0.035$ \\
Cholesterol, mmol/L & $4.36^{\mathrm{b}} \pm 0.39$ & $4.07^{\mathrm{b}} \pm 0.38$ & $3.93^{\mathrm{a}} \pm 0.38$ \\
Prolactin, ng/mL & $81.98^{\mathrm{A}} \pm 20.65$ & $134.82^{\mathrm{B}} \pm 16.94$ & $96.16^{\mathrm{A}} \pm 16.94$ \\
Growth hormone, ng/mL & $4.86 \pm 0.86$ & $4.58 \pm 0.70$ & $5.10 \pm 0.70$ \\
Cortisol, ng/mL & $4.68 \pm 0.80$ & $2.90 \pm 0.85$ & $3.19 \pm 0.84$ \\
Leptin, ng/mL & $3.52 \pm 0.16$ & $3.40 \pm 0.15$ & $3.40 \pm 0.15$ \\
\hline
\end{tabular}

${ }^{\mathrm{a}, \mathrm{b}} P<0.05 ;{ }^{\mathrm{A}, \mathrm{B}} P<0.01$

\section{Leptin and Leptin Receptor Gene Expression}

Expression of leptin and the long and short forms of leptin receptor mRNA in AT is shown in Figure 5. Cows exposed to long DL had greater expression of leptin $(P$ $<0.01$ ) compared with cows in neutral and short DL. Day length also significantly affected gene expression of both forms of leptin receptor. Compared with neutral $\mathrm{DL}$, long DL up-regulated $\mathrm{Ob}-\mathrm{Rb}(P<0.05)$ and $\mathrm{Ob}-\mathrm{Ra}$ $(P<0.01)$ gene expression, whereas short DL downregulated $(P<0.01)$ leptin receptors gene expression.

\section{Correlation Analysis}

Leptin mRNA was positively related with PRL ( $\mathrm{r}=$ $0.57, P<0.05)$. That relationship increased when only

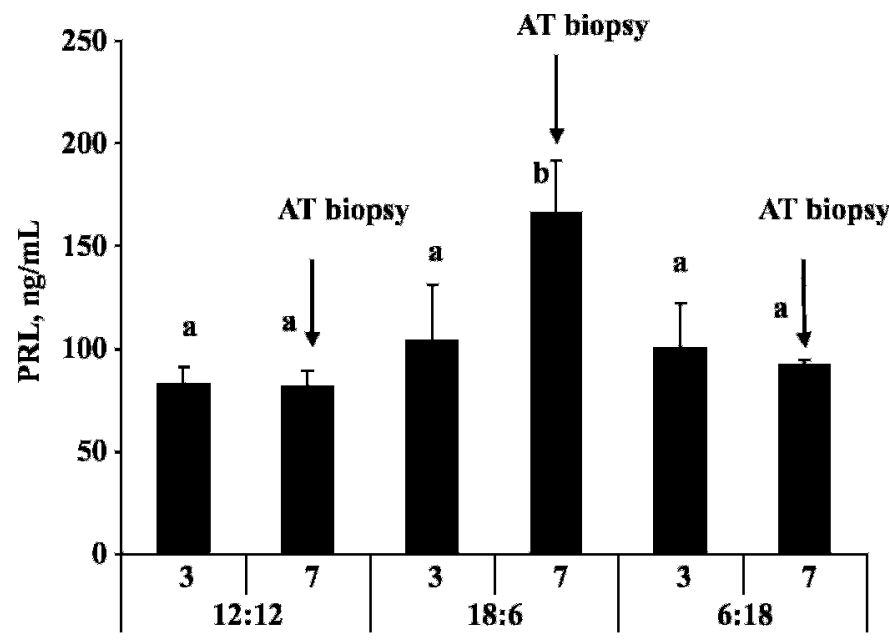

Days from the beginning of the treatment

Figure 4. Least squares means $\pm \mathrm{SE}$ for plasma prolactin (PRL) concentration. Each bar represents the average of d 3 or $d 7$ of the experimental periods; photoperiods are 12:12, 18:6, and $6: 18 \mathrm{~h}$ of light:dark. The arrows indicate the day in which adipose tissue (AT) biopsies were carried out. ${ }^{\mathrm{a}, \mathrm{b}} P<0.05$. data recorded under long DL were considered $(\mathrm{r}=0.89$, $P<0.05)$. Plasma $\mathrm{PRL}$ was positively related with $\mathrm{Ob}-$ $\mathrm{Ra}(\mathrm{r}=0.69, P<0.05)$ and $\mathrm{Ob}-\mathrm{Rb}(\mathrm{r}=0.52, P<0.05)$
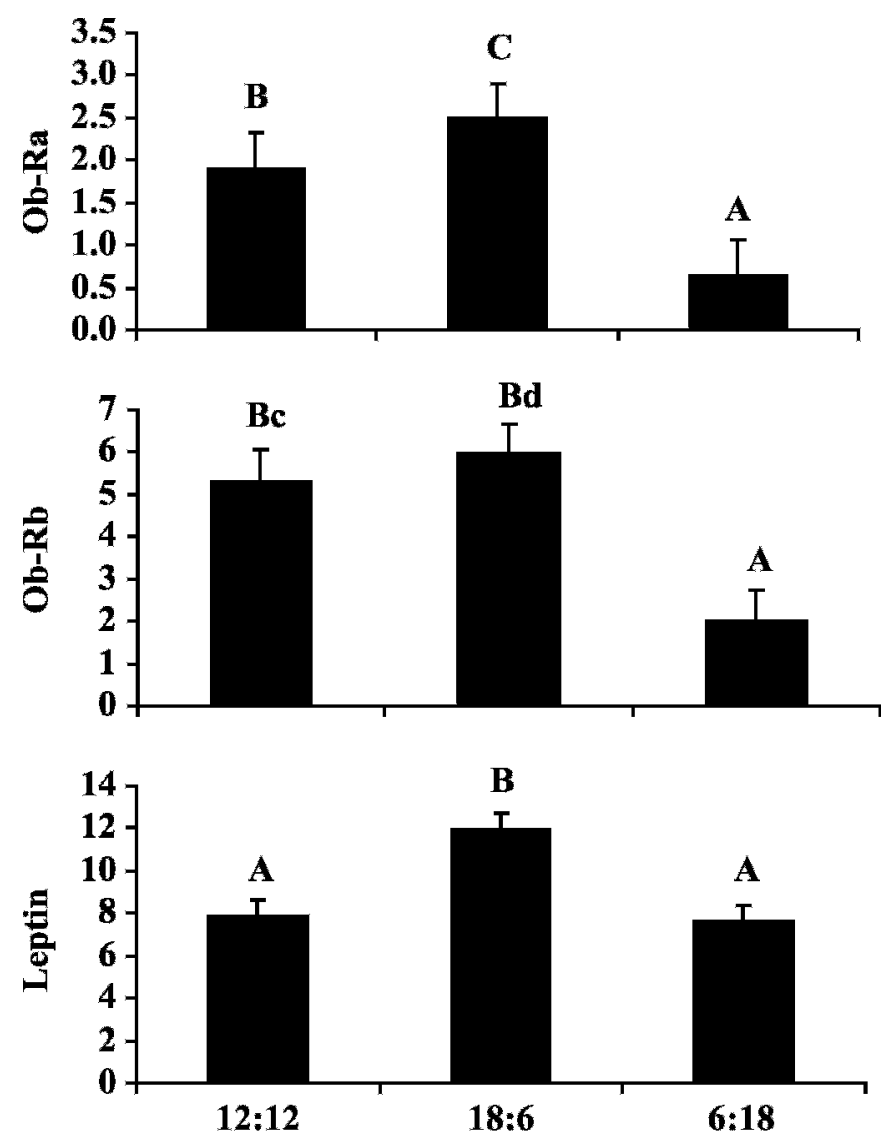

Photoperiod, hours of light:dark

Figure 5. Least squares means $\pm \mathrm{SE}$ for short form leptin receptor (Ob-Ra, upper), long-form leptin receptor (Ob-Rb, middle), and leptin (bottom) mRNA abundance (pg of mRNA/ $\mu$ g of total RNA) in adipose tissue of lactating dairy cows exposed to different photoperiod: 12:12, 18:6, and 6:18 represent hours of light:dark. ${ }^{\mathrm{A}-\mathrm{C}} P<0.01$; ${ }^{\mathrm{c}, \mathrm{d}} P<0.05$. 
mRNA. No relationships were observed between circulating leptin and leptin mRNA.

\section{DISCUSSION}

The present study provides the first evidence that exposure to a short-term photoperiod significantly affects gene expression of leptin and its receptors in AT of lactating dairy cows. Compared with the neutral phase, leptin and its receptor transcripts were higher when animals were exposed to long DL, whereas Ob-Ra and Ob-Rb decreased during the short DL exposure, while having no effect on circulating leptin.

Studies in ruminants indicated that short-term regulation of leptin expression involves complex interactions between blood metabolites (glucose, NEFA, BHBA) and hormone secretion (insulin, GH, glucocorticoids). Chilliard et al. (2005) reported that response of plasma leptin to meal intake in cows was related positively with glycemia, and negatively with plasma BHBA. A negative correlation between leptin and NEFA was reported in dairy cows (Bloch et al., 2001). Positive relationships between plasma leptin and cholesterol concentration were reported in ruminants (Houseknecht et al., 1998). Growth hormone and glucocorticoids (cortisol) are recognized as positive regulators of AT leptin gene expression in cattle (Houseknecht et al., 2000).

In the present study, due to the short duration of light alteration ( $1 \mathrm{wk} / \mathrm{phase}$ ), no differences in feed intake and BCS were observed between photoperiod phases. Furthermore, no significant changes were observed for plasma metabolites, except cholesterol, and $\mathrm{GH}$ and cortisol during all over the experimental period. Changes of leptin mRNA could not be regulated by changes in adiposity, nutritional factors, or intermediary of metabolism and hormones, but might be assigned to a direct effect of photoperiod on AT. In this regard, Bocquier et al. (1998) reported that AT leptin mRNA expression was modulated by DL independently from feed intake, body fatness, and gonadal activity in ovariectomized ewes.

The mechanisms involved with photoperiodic influences of AT leptin expression are not well known. The effects of DL on leptin and leptin receptors gene expression may be due to neural-hypothalamic changes in sensitivity to DL. The direct effect of the sympathetic nervous system and the interactions between melatonin and PRL may be involved (Dahl et al., 2000). In cattle and other mammals, photoperiodic perception occurs at the retina. Light impinging on the eye stimulates retinal photoreceptors that transmit an inhibitory signal to the pineal gland through a series of interneurons (Rieter, 1991). Of the hormones secreted by the pineal gland, melatonin is generally accepted as the mediator of photoperiodic responses. A possible peripheral direct effect of melatonin secretory pattern on leptin gene expression or secretion is plausible, because specific functional melatonin receptors have been described in human adipocytes (Brydon et al., 2001). Moreover, melatonin acts directly in the pituitary gland to mediate the effects of photoperiod on PRL secretion. In particular, Lincoln and Clarke (1994) demonstrated that the melatonin signal induces a marked decrease in PRL secretion.

Prolactin plays a role in various physiological processes. Prolactin can modulate AT lipid metabolism, during adipocyte differentiation and in mature adipocytes (Symonds et al. 1998). In our conditions, the increase of leptin mRNA under long DL was consistent with shifts of plasma PRL concentrations. Furthermore, correlation analysis confirmed the association between PRL and leptin mRNA. On the other hand, our results on PRL changes are consistent with those reported by Accorsi et al. (2005) in lactating dairy cows, and by Bocquier et al. (1998) in sheep, who observed that plasma PRL was increased by long DL and reduced by short DL. On a theoretical basis, PRL might affect AT leptin gene expression through a direct mechanism mediated by PRL receptors on adipocytes (McAveney et al., 1996).

In the current study, we analyzed the gene expression of leptin receptors (Ob-Rb and $\mathrm{Ob}-\mathrm{Ra}$ ) in bovine AT in relation to DL. Expression of leptin receptor mRNA in the AT was previously reported in cows (Chelikani et al., 2003). The presence of Ob-Rb and Ob-Ra transcripts in adipocytes suggests that leptin acts directly through receptors activation to regulate lipid metabolism in adipocytes (Frühbeck et al., 1998). Changes of leptin receptor mRNA in AT are consistent with shifts of plasma PRL concentrations. Furthermore, correlation analysis confirms the association between PRL and receptors gene expression. In a recent study, Feuermann et al. (2004) reported that PRL could regulate leptin and its receptor gene expression in the bovine mammary gland. In particular, PRL enhanced leptin receptors approximately 25 times and there was a 2.2 -fold increase in leptin mRNA expression in the mammary gland of lactating cows. On the basis of our results and findings of Feuermann et al. (2004), we suggest that the upregulation of AT leptin receptors gene expression during the exposure to long DL might be mediated by PRL; therefore, it would be responsible for the modulation of AT sensitivity to leptin.

In spite of the response of leptin mRNA to different DL exposure, no variations of circulating levels of leptin were observed in the present study. In agreement with present findings, Garcia et al. (2002) found no relation- 
ship between circulating leptin and AT leptin gene expression in prepubertal heifers. Those authors justified their results on the basis of the differences between the number of serum and AT samples. In our study, we had similar conditions to Garcia et al. (2002). Other than sampling regimen, an early increase of leptin gene expression that may precede the rise in circulating leptin might be a possible explanation. Another possible explanation about the absence of relationship between leptin mRNA and plasma leptin might be an important autocrine role of leptin in AT. Autocrine lipolytic effects of leptin on adipocytes both in vitro and in vivo studies are well documented (Frühbeck et al., 1998). Furthermore, the same authors reported that leptin represses acetyl-CoA carboxylase gene expression, fatty acid synthesis, and lipid synthesis in AT, without the participation of the brain. Therefore, leptin is involved in the direct regulation of AT metabolism by inhibiting lipogenesis and stimulating lipolysis. These findings, show that the control of energy balance requires not only leptin actions at the hypothalamic level, but there is a distinct autocrine action of leptin on AT.

The regulation of leptin and its receptor gene expression by photoperiod could play a role in the natural adaptations to environmental factors. In dairy cattle photoperiod affects growth, immune function, reproduction, and lactation (Dahl et al., 2000). Garcia et al. (2002) demonstrated the close relationship between circulating and AT gene expression of leptin and pubertal onset. Our results on the effect of photoperiod on leptin and leptin receptor gene expression, together with findings from others (Garcia et al., 2002), suggest that the positive effects of long DL on reproduction in cattle may be mediated by leptin modulation.

The galactopoietic effect of photoperiod has been confirmed (Dahl et al., 2000). Increase in DL positively affects MY. Moreover, long days increase circulating concentration of PRL. Even though PRL effects are likely not involved in the lactation response, PRL is one component of a hormonal complex that regulates galactopoeisis. Leptin is known to play an important role in the bovine mammary gland lactogenesis. Feuermann et al. (2004) demonstrated that mammary gland leptin and leptin receptor gene expression can be regulated by PRL, and that leptin may interact with PRL during lactation to alter milk synthesis. They found that, in presence of PRL, leptin enhanced fatty acid synthesis and elevated the expression of $\alpha_{\mathrm{S}}$-casein and $\beta$-lactoglobulin in bovine mammary gland. On the basis of Feuermann et al. (2004) findings and results of the present study, PRL and leptin appear to be possible candidates to explain the effects of photoperiod on milk production.

\section{CONCLUSIONS}

Results of the present study suggest that variations in gene expression of leptin and leptin receptors in AT of lactating dairy cows are directly induced by photoperiod. A possible PRL-mediated effect of photoperiod on AT leptin modulation was established in lactating dairy cows. Changes of leptin and its receptor gene expression, induced by photoperiod, could be an important factor in modifying the physiological responses (reproduction, milk production) observed in dairy cattle throughout the year. Finally, further study using a larger sample size would be helpful to corroborate the results of the present research.

\section{ACKNOWLEDGMENTS}

The authors acknowledge the technical help provided by C. Bruti.

\section{REFERENCES}

Accorsi, P. A., N. Govoni, R. Gaiani, C. Pezzi, E. Seren, and C. Tamanini. 2005. Leptin, GH, PRL, insulin and metabolic parameters throughout the dry period and lactation in dairy cows. Reprod. Domest. Anim. 40:217-223.

Agricultural Development and Advisory Service. 1986. Condition scoring of dairy cows. Publ. 612, Agric. Dev. Advisory Serv., Min. Agric., Fisheries Food (Publ.), Lion House, Alnwick, UK.

Ahima, R. S., and J. S. Flier. 2000. Leptin. Annu. Rev. Physiol. 62:413-437.

AOAC. 1984. Official Methods of Analysis. 14th ed. Association of Official Analytical Chemists, Washington, DC.

Barnouin, J., N. El. Idilbi, Y. Chilliard, J. P. Chacornac, and R. Lefaivre. 1986. Automatic micro-dosage without deproteinization of bovine plasma 3-hydroxybutyrate. Ann. Rech. Vet. 17:129-139.

Bernabucci, U., B. Ronchi, L. Basiricò, D. Pirazzi, F. Rueca, N. Lacetera, and A. Nardone. 2004. Abundance of mRNA of apolipoprotein B100, apolipoprotein E and microsomal triglyceride transfer protein in liver from periparturient dairy cows. J. Dairy Sci. 87:2881-2888.

Bloch, S. S., W. R. Butler, R. A. Ehrhardt, A. W. Bell, M. E. Van Amburgh, and Y. R. Boisclair. 2001. Decreased concentrations of plasma leptin in periparturient dairy cows is caused by negative energy balance. J. Endocrinol. 171:339-348.

Bocquier, F., M. Bonnet, Y. Faulconnier, M. Guerre-Millo, P. Martin, and Y. Chilliard. 1998. Effects of photoperiods and feeding level on perirenal AT metabolic activity and leptin synthesis in the ovariectomized ewe. Reprod. Nutr. Dev. 38:489-498.

Brydon, L., L. Petit, P. Delagrange, A. D. Strosberg, and R. Jockers. 2001. Functional expression of MT2(Mel1b) melatonin receptors in human PAZ6 adipocytes. Endocrinology 142:4264-4271.

Chelikani, P. K., D. R. Glimm, and J. J. Kennelly. 2003. Tissue distribution of leptin and leptin receptor mRNA in the bovine. J. Dairy Sci. 86:2369-2372.

Chilliard, Y., C. Delavaud, and M. Bonnet. 2005. Leptin expression in ruminants: Nutritional and physiological regulation in relation with energy metabolism. Domest. Anim. Endocrinol. 29:3-22.

Dahl, G. E., B. A. Buchanan, and H. A. Tucker. 2000. Photoperiodic effects on dairy cattle: A review. J. Dairy Sci. 83:885-893.

Delavaud, C., F. Bocquier, Y. Chilliard, D. H. Keisler, A. Gertler, and G. Kann. 2000. Plasma leptin determination in ruminants: Effect of nutritional status and body fatness on plasma leptin concentration assessed by a specific RIA in sheep. J. Endocrinol. 165:519-526. 
Feuermann, Y., S. J. Mabjeesh, and A. Shamay. 2004. Leptin affects prolactin action on milk protein and fat synthesis in the bovine mammary gland. J. Dairy Sci. 87:2941-2946.

Frühbeck, G. 2001. A heliocentric view of leptin. Proc. Nutr. Soc. 60:301-318

Frühbeck, G., M. Aguado, J. Gomez-Ambrosi, and J. A. Martinez. 1998. Lipolytic effect of in vivo leptin administration on adipocytes of lean and ob/ob mice, but not db/db mice. Biochem. Biophys. Res. Commun. 250:99-102.

Garcia, M. R., M. Amstalden, S. W. Williams, R. L. Stanko, C. D. Morrison, D. H. Keisler, S. E. Nizielski, and G. L. Williams. 2002. Serum leptin and its adipose gene expression during pubertal development, the estrous cycle, and different seasons in cattle. J. Anim. Sci. 80:2158-2167.

Goering, H. K., and P. J. Van Soest. 1970. Forage Fiber Analyses (Apparatus, Reagents, Procedures, and Some Applications). Agric. Handbook no. 379. ARS-USDA, Washington, DC.

Houseknecht, K. L., C. A. Baile, R. L. Matteri, and M. S. Spurlock. 1998. The biology of leptin: A review. J. Anim. Sci. 5:1405-1420.

Houseknecht, K. L., C. P. Portocarrero, S. Ji, R. Lemenager, and M. E. Spurlock. 2000. Growth hormone regulates gene expression in bovine adipose tissue: Correlation with adipose IGF-I expression. J. Endocrinol. 164:51-57.

Lincoln, G. A., and I. J. Clarke. 1994. Photoperiodically induced cycles in the secretion of prolactin in hypothalamo-pituitary disconnected rams: Evidence for translation of the melatonin signal in the pituitary gland. J. Neuroendocrinol. 6:251-260.

McAveney, M. K., J. M. Gimble, and L. Y. Yu Lee. 1996. Prolactin receptor expression during adipocytes differentiation of bone marrow stroma. Endocrinology 137:5723-5726.

Rieter, R. J. 1991. Pineal melatonin: Cell biology of its synthesis and of its physiological interactions. Endocr. Rev. 12:151-180.

Ronchi, B., G. Stradaioli, A. Verini Supplizi, U. Bernabucci, N. Lacetera, P. A. Accorsi, A. Nardone, and E. Seren. 2001. Influence of heat stress and feed restriction on plasma progesterone, estradiol$17 \beta$, LH, FSH, prolactin and cortisol in Holstein heifers. Livest. Prod. Sci. 68:231-241.

SAS Institute. 1999. SAS User's Guide: Statistics, Version 8.0 Edition. 1999. SAS Inst., Inc., Cary, NC.

Symonds, M. E., I. D. Phillips, R. V. Anthony, J. A. Owens, and I. C. McMillen. 1998. Prolactin receptor expression and foetal adipose tissue. J. Neuroendocrinol. 20:885-890.

Sweeney, G. 2002. Leptin signaling. Cell. Signal. 14:655-663. 